\title{
The (in)accuracy of official work stoppage statistics in New Zealand
}

\author{
Raymond Harbridge*
}

The accuracy of stoppage statistics in New Zealand is examined by comparing official statistics of the Federation of Labour's right to bargain campaign with those collected at Victoria University of Wellington. The campaign of industrial stoppages lasted 87 days and was identified using media reports and employer and union sources. A total of 57264 workers stopped work, losing a total of 126793 working days. Government figures under-report the number of workers involved in the campaign stoppages by 47 percent and the number of working days lost by 42 percent. The degree of under-reporting is even more marked when the activities of 2 groups of workers - meat processing workers and waterside workers - are taken out of the sample. Then, working days lost in the manufacturing sector are under-reported by 117 percent while in the transport sector official figures reveal a mere 82 workers losing 198 days while university figures identified 9440 workers losing 6360 working days.

Reasons for these inaccuracies include the low priority given to the function of collecting stoppage statistics within the Department, and staffing difficulties while at the same time the Department's work load was being increased. It is often argued that while the raw stoppage statistics are inaccurate, they do accurately reflect trends in industrial disputation. The research indicates that this is not the case and that policy makers should not rely on stoppage statistics as a means to evaluate the effectiveness of the industrial relations system.

\section{Introduction}

Official stoppage statistics are used from time to time to draw conclusions regarding the effectiveness of Government policy in the area of industrial relations. Politicians sometimes use the statistics to argue the success of their government's policies, compared with that of earlier administrations (for example see Rodger, 1985). In addition to their use in examining the effectiveness of the policies of different administrations, New Zealand's stoppage statistics are compared against those of other countries - presumably to draw conclusions regarding the effectiveness of New Zealand's industrial relations compared to the industrial relations systems of other countries, and possibly by overseas investors anxious to learn more about the industrial climate in New Zealand (for example see Jackman, 1985). By international standards New Zealand tends to have a fairly high number of working days lost per 1000 workers but stoppages in New Zealand have a comparatively low average duration.

The inaccuracy of stoppage statistics and the difficulties of international comparisons are well known and documented elsewhere, for example in Shalev (1978a and 1978b), and Ingham (1974). In New Zealand the accuracy of stoppage statistics has been a concern of the Department of Statistics. The Department of Statistics initiated meetings with officers of the Department of Labour in early 1985, with a view to shortening the length of time taken to collect the statistics and ensuring that adequate coverage of stoppages was being achieved (Department of Labour, 1985a).

* Senior Lecturer. Industrial Relations Centre, Victoria University of Wellington

The author wishes to thank research assistant Don Edwards, Rosalie Webster of the Department of Labour for her assistance with supplying the official data discussed in this paper. and Dave Atmore for assistance with computer programming. This research was supported by research grant $76 / 85$ of Victoria University's Internal Research Committee and a grant from the Industrial Relations Centre. 


\section{The collection of official stoppage statistics}

The responsibility for the collection of stoppage statistics in New Zealand lies with the head office (Industrial Relations Division) of the Department of Labour. The head office instructions to district offices on the collection of stoppage statistics are contained in a departmental circular dated 20 November 1984 which expands on instructions given in 1976 (Department of Labour. 1984). The information sought by head office is required for 2 purposes. First, the collection of stoppage statistics and second, to enable a weekly report to the Minister of Labour. detailing current disputes. The Department's district offices are asked to report on all unauthorised stoppages of work or reductions in normal work output which arise in the course of an industrial dispute or protest action or stopworks to discuss union matters, irrespective of whether the action is recognised under New Zealand's industrial laws and regardless of the duration of the stoppage (Department of Labour, 1976). The information collected locally is forwarded to head office, checked and ultimately forwarded to the Department of Statistics.

\section{The right to bargain campaign}

In 1984, in the 3 months prior to the "snap" general election of July 14 , trade unions, acting under the auspices of the Federation of Labour (FOL), mounted a campaign of industrial stoppages designed to restore their rights to bargain over wages and conditions. Those rights had been suspended in June 1982 by the Wage Freeze Regulations 1982 issued by the Government under the Economic Stabilisation Act 1948. The background to the union campaign along with its impact and effectiveness has been reported earlier (Harbridge and Edwards, 1985). In the 3 months of the campaign, a wide range of industries and employers became the target for industrial action. Two industries however, the meat processing industry and the waterfront industry, were particularly prominent on a national basis, and were clearly a significant force in shaping the campaign.

The actions of meatworkers and watersiders were easily identifiable stoppage activities. The stoppage activities of other groups of workers were possibly less obvious yet seemed to be widely reported, industry by industry, across the country, in daily media reports. That the stoppages occurred within a finite period, and that the cause of the stoppages was clear, made the campaign an ideal instrument with which to measure the accuracy of official statistics.

\section{University stoppage statistics collection}

Evidence of this industrial campaign was initially sought by examining newspaper reports of the campaign in 10 of New Zealand's 30 daily newspapers. The information provided in the newspaper item was checked with the employer and union cited. Many employers and unions contacted were able to identify other disputes that had not received newspaper coverage. Other disputes were identified by direct contact with officials of the FOL and the New Zealand Employers Federation. These additional disputes were checked and are included in their results. Each dispute observed has been recorded as a separate dispute. Where a second strike or other action followed, that action was not recorded as a new dispute but as a continuation of the first dispute. The definition of a work stoppage used was identical to that used by the Department of Labour - concentrating on unauthorised industrial stoppages where production time was lost - through extended stop work meetings, one-day stoppages, protracted strikes, or load-out bans.

\section{Results}

The campaigr of industrial action lasted 87 days. In that period 152 work stoppages were identified. Of these stoppages, 56 involved the New Zealand's Meatworkers Union, 12 involved the New Zealand Waterside Workers' Union, and the remaining 84 stoppages were spread over a wide range of industries. Official figures do not separately report the number of stoppages recorded. In the following results, the statistics in parentheses are the official
statistics. 
Throughout New Zealand, a total of 57264 (38 895) workers took direct action supporting the campaign. A total of 126793 (89 228) working days were lost as a result. The figures presented in Table 1 analyse the stoppages by industrial district and calculate the percentage that the official statistics understate the level of stoppages observed. Most stoppages occurred in the Northern industrial district with 27037 (11 741) workers being involved, losing 54972 (27 716) working days.

Table 1: Wage freeze work stoppages by industrial district

\begin{tabular}{|c|c|c|c|c|c|c|}
\hline & \multicolumn{3}{|c|}{ Number of workers involved } & \multicolumn{3}{|c|}{ Number of working days lost } \\
\hline & $\begin{array}{l}\text { Government } \\
\text { statistics }\end{array}$ & $\begin{array}{l}\text { University } \\
\text { statistics }\end{array}$ & $\begin{array}{l}\text { \% understatement } \\
\text { of government } \\
\text { statistics }\end{array}$ & $\begin{array}{l}\text { Government } \\
\text { statistics }\end{array}$ & $\begin{array}{l}\text { University } \\
\text { statistics }\end{array}$ & $\begin{array}{l}\text { \% understatement } \\
\text { of government } \\
\text { statistics }\end{array}$ \\
\hline Northern & 11741 & 27037 & $130 \%$ & 27716 & 54972 & $98 \%$ \\
\hline Taranaki & 3079 & 3661 & $19 \%$ & 7071 & 11055 & $56 \%$ \\
\hline Wellington & 8440 & 9588 & $13 \%$ & 21505 & 24517 & $14 \%$ \\
\hline Marlborough & & & & & & \\
\hline Nelson/Westland & 1186 & 1473 & $24 \%$ & 1717 & 3161 & $84 \%$ \\
\hline Canterbury & 5668 & 6192 & $9 \%$ & 9728 & 10774 & $11 \%$ \\
\hline Otago/Southland & 8781 & 9313 & $6 \%$ & 21491 & 22314 & $4 \%$ \\
\hline Other* & - & 3000 & - & - & 1800 & - \\
\hline TOTAL & 38895 & 57264 & $47 \%$ & 89228 & 126793 & $42 \%$ \\
\hline
\end{tabular}

* Unauthorised inter-union stop work meetings. generally around 4 hours duration, held across industries.

Across New Zealand, the official statistics understate the number of workers involved by 47 percent and the number of working days lost by 42 percent. Most under statement however occurred within the Northern industrial district where the number of workers involved was understated by 130 percent and the number of working days lost by 98 percent. In the Taranaki and Marlborough/Nelson/Westland industrial districts the percentage understatement of working days lost is far greater than the percentage understatement of workers involved. indicating that while stoppages and numbers of workers were recorded comparatively accurately, estimates of the duration of the stoppages fell far short of their actual duration.

The right to bargain campaign was concentrated in the manufacturing sector of the New Zealand economy. A total of 37805 (33 694) workers lost 99400 (79 971) working days in this sector. The figures presented in Table 2 analyse the stoppages by industrial sector and calculate the percentage that the official statistics understate the stoppages recorded.

Table 2: Wage freeze work stoppages by all industries

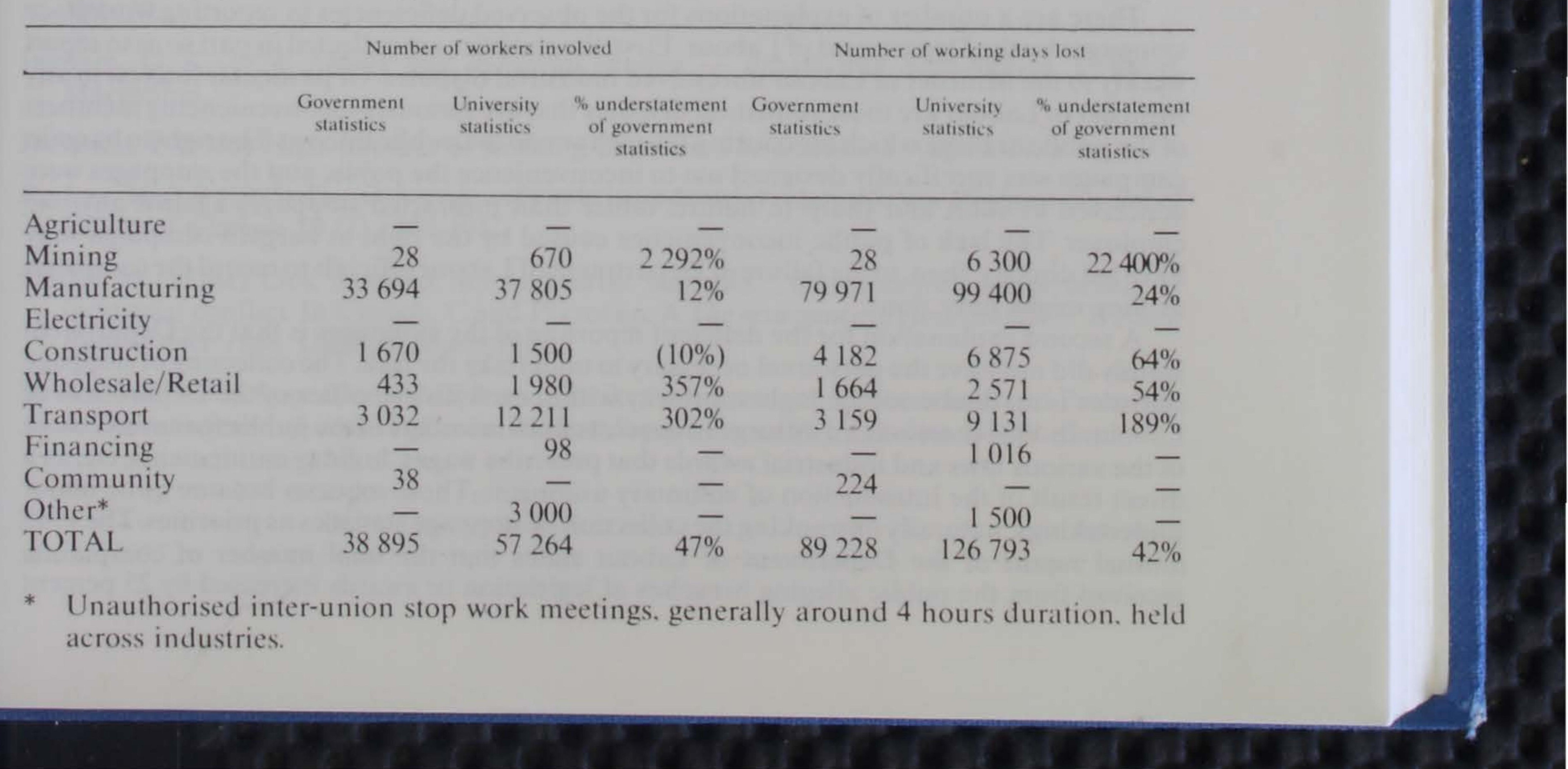


The activities of the New Zealand Meatworkers' Union and the New Zealand Waterside Workers' Union accounted for exactly 50 percent of workers involved and working days lost. In order to examine the impact of these 2 unions within their respective industrial sectors, the stoppage statistics were examined by the manufacturing and transport industries. Taken overall, the Government official statistics in the manufacturing sector understate the number of workers involved by 12 percent and working days lost by 24 percent. The closeness of university and Government statistics is due to the magnitude and accuracy of the meat slaughtering statistics. Stoppages in other parts of the manufacturing sector were substantially understated both in terms of the number of workers involved, 11912 (6 564) workers, an 82 percent understatement, and numbers of working days lost, 37987 (17 483), a 117 percent understatement. The position in the transport sector shows a similar pattern with the understatement of stoppages in the "other transport" sector being very substantial. University and Government statistics relating to stoppages in port operations are similar. In the "other transport" sector however 9440 workers were recorded as losing 6360 working days by university figures while Government statistics disclose a mere 82 workers losing 198 working days.

The combined actions of the meatworkers and watersiders account for 50 percent of all workers involved and 50 percent of all working days lost, yet their activities dominate Government statistics accounting for 77 percent of all workers involved and 73 percent of all working days lost.

\section{Discussion}

Taken overall. Government statistics understated stoppages by between 40 and 50 percent. and this itself is a cause for concern. Of greater concern however, is that Government statistics give an illusion of overall accuracy by the accurate reporting of stoppages in 2 industrial subsectors. meat slaughtering and port operations, while largely ignoring stoppages in other sectors of the economy. That stoppages in these 2 industrial sub-sectors is so accurate is hardly surprising. The New Zealand Freezing Companies Association, a parent body for the various meat slaughtering companies, undertakes the collection of data on workplace disputes, collates the material and, if requested, makes a return directly to the Department of Labour's head office. The New Zealand Harbour Boards Association, a parent body to the various harbour boards, follows a similar procedure. Both associations provided statistics for this research. Their emphasis on collecting their own statistics and providing them to the Department of Labour is no doubt the reason for the accuracy of the official statistics.

Of real concern is that, when the stoppages by meatworkers and watersiders are excluded from the official data, the remaining official statistics report a mere fraction of the workplace stoppages that took place. The principal areas of deficient reporting occur in the Northern industrial district and in the transport (except port operations), manufacturing (except meat slaughtering), and wholesale/retail industrial sectors.

There are a number of explanations for the observed deficiencies in reporting workplace stoppages by the Department of Labour. First, the statistics are collected in part so as to report weekly to the Minister of Labour unresolved industrial disputes. Of particular interest to any Minister of Labour are those industrial disputes that a re seriously inconveniencing members of the public or those which are causing severe harm to the public interest. The right to bargain campaign was specifically designed not to inconvenience the public and the stoppages were conceived as short and sharp in nature, rather than protracted stoppages against any one employer. The lack of public inconvenience caused by the right to bargain campaign may have led directly, then, to the failure of Department of Labour officials to record the campaign
as they might have done.

A second explanation for the deficient reporting of the stoppages is that the Department simply did not have the personnel necessary to undertake the task. The collecting of stoppage statistics is no doubt not the highest priority within each district office of the Department of Labour. In 1984 there was an upsurge in requests from members of the public for enforcement of the various laws and industrial awards that prescribe wages, holiday entitlements, etc, as a direct result of the introduction of voluntary unionism. These requests became quite major undertakings, naturally outranking the collection of stoppage statistics as priorities. The 1985 annual report of the Department of Labour states that the total number of complaints received from the public alleging breaches of legislation or awards increased by 25 percent 
over the number received in the previous year. The report concludes "The main reasons for this increase include the introduction of voluntary unionism ....." (Department of Labour, 1985b, p44).

Thus the particular circumstances of 1984 may mean that stoppage statistics were more unreliable than usual, due to the re-deployment of staff to more important matters. Notwithstanding these explanations, it is surprising that the official statistics are so deficient. Data collection undertaken at the university used a careful examination of the daily presses to identify the stoppages and this technique is commonly used by stoppage statistic collection agencies in other countries. No doubt a similar exercise by officials at the Department of Labour's head office, would have revealed the diversity of the campaign identified in the university's statistics.

It has been said that while stoppage statistics may not be accurate as absolute statistics, they are useful in accurately portraying trends in a country's industrial relations. The research presented in this paper would support this contention only so far as it applies to the meat slaughtering and port operation industries. Trends in those industries are no doubt accurately portrayed in New Zealand's stoppage statistics. Given the paucity of statistics in other sectors however, it is unlikely that any "trends" could be accurately identified from the official statistics, and it would be a brave academic in the 1980 s who would want to hypothesise that industrial relations in the meat industry or on the waterfront in any way represented industrial relations trends. This is particularly so given the current decline of those 2 industries, and the growth of other industries important in the context of the national economy. The usefulness of New Zealand's stoppage statistics as a means of evaluating the effectiveness of industrial relations policy is questionable given the shortfalls demonstrated by this research.

\section{References}

Department of Labour (1976) Revised industrial stoppage forms Departmental Circular Volume 8. circular number 619. Wellington, Department of Labour.

Department of Labour (1984) Completion of stoppage report forms/monitoring of industrial relations Departmental Circular Volume 8, circular number 873 . Wellington. Department of Labour.

Department of Labour (1985a) Collection of stoppage statistics Department Circular Volume 8, circular number (not given). Wellington, Department of Labour.

Department of Labour (1985b) Report of the Department of Labour for the year ended 31 March 1985 Wellington, Government Printer.

Harbridge, R and Edwards, D (1985) The Federation of Labour's right to bargain campaign : its background, impact and effectiveness New Zealand journal of industrial relations 10 (3): 129-139.

Ingham, G K (1974) Strikes and industrial conflict - Britain and Scandinavia. London, Macmillan.

Jackman, P (1985) High number of working days lost The Dominion August 29, p 7.

Rodger, Hon S (1985) The Government's role in industrial relations New Zealand journal of industrial relations 10 (2) : 103-104.

Shalev M (1978a) Lies, damned lies and strike statistics : the measurement of trends in industrial conflict. In Crouch, $\mathrm{C}$ and Pizzorno, A The resurgence of class conflict in Western Europe since 1968. London. Macmillan.

Shalev, M (1978b) Appendix II Problems of strike measurement. In Crouch, C and Pizzorno. A The resurgence of class conflict in Western Europe since 1968. London. Macmillan. 